\title{
Evaluation of body painful areas in patients with muscular temporomandibular disorder: a retrospective study
}

\author{
Avaliação das áreas de dor no corpo em pacientes com disfunção temporomandibular \\ muscular: estudo retrospectivo
}

Luci Mara França Correia ${ }^{1}$, Antonio Sergio Guimarães ${ }^{1}$, Marcelo Luschesi Teixeira ${ }^{1}$, Luciane Lacerda Rodrigues ${ }^{1}$

DOI 10.5935/1806-0013.20150050

\section{ABSTRACT}

BACKGROUND AND OBJECTIVES: Among temporomandibular disorder classifications, masticatory muscles myofascial pain is the most frequent. Its multifactorial etiology makes its treatment difficult. Identifying other painful sites related to temporomandibular disorders may help controlling comorbidities and, as a consequence, improving their symptoms. This study aimed at evaluating the presence of body pain in temporomandibular disorder patients, the frequency of such reports and their location.

METHODS: We have evaluated 328 medical charts of the Dental Research Center São Leopoldo Mandic, with diagnosis of muscular temporomandibular disorder. Patients were evaluated by means of a body map to locate pain complaints.

RESULTS: From 328 analyzed medical charts, 180 (55\%) had body pain (160 females, 20 males), and 148 (45\%) had facial pain only (116 females, 32 males). Areas with most frequent pain reports were cervical, lumbar and shoulders. Females had more body pain (with pain $\mathrm{n}=160$, without pain $\mathrm{n}=116, \mathrm{p}<0.001$ ) as compared to males (with pain $n=20$, without pain $n=32$ ) with statistical difference. In most cases pain has affected both body sides (bilateral face $67 \%$, bilateral body $92 \%$ ).

CONCLUSION: Most patients with temporomandibular disorder had pain in body parts different from the face. Regions marked in human body drawings with more pain were cervical followed by lumbar and shoulders.

Keywords: Cervical pain, Generalized pain, Myofascial pain, Temporomandibular disorder.

1. Centro de Pesquisa Odontológica São Leopoldo Mandic, Departamento de Mestrado em Dor e Disfunçăo Temporomandibular, Campinas SP, Brasil.

Submitted in October 23, 2014.

Accepted for publication in October 15, 2015.

Conflict of interests: none - Sponsoring sources: none.

Correspondence to:

Luci Mara França Correia

Rua Paraíba, 2902 - Bairro Guaíra

80630-000 Curitiba, PR, Brasil.

E-mail: draluci.odonto@gmail.com

(C) Sociedade Brasileira para o Estudo da Dor

\section{RESUMO}

JUSTIFICATIVA E OBJETIVOS: Dentre as classificaçôes das disfunçôes temporomandibulares, as dores miofasciais nos músculos da mastigação são as mais frequentes. Sua etiologia multifatorial dificulta o tratamento. Reconhecer outros locais de dor relacionados à disfunção temporomandibular pode ajudar no controle das comorbidades e consequentemente melhorar o seu quadro. O objetivo deste estudo foi avaliar a presença de dor no corpo em pacientes com disfunção temporomandibular, a frequência desses relatos e sua localização.

MÉTODOS: Foram avaliados 328 prontuários do Centro de Pesquisa Odontológica São Leopoldo Mandic, com diagnóstico de disfunção temporomandibular muscular. Os pacientes foram avaliados por meio de desenhos de mapa corporal para determinar a localização de queixas de dor.

RESULTADOS: Dos 328 prontuários analisados, 180 (55\%) apresentaram registro de dor pelo corpo (160 mulheres, 20 homens), e 148 (45\%) apresentavam dor apenas na regiáo da face (116 mulheres, 32 homens). As áreas com maior relato de dor foram: cervical, lombar e ombros. O gênero feminino apresentou maior frequência de dores no corpo (com dor $n=160$, sem dor $\mathrm{n}=116, \mathrm{p}<0,001$ ) que o gênero masculino (com dor $\mathrm{n}=20$ e sem dor $\mathrm{n}=32$ ) com diferença estatística. $\mathrm{Na}$ maior parte dos casos a dor acometeu os dois lados do corpo (face 67\% bilateral e corpo $92 \%$ bilateral)

CONCLUSÁO: A maioria dos pacientes com diagnóstico de disfunçáo temporomandibular apresentou dor em outras partes do corpo além da face. A região anotada nos desenhos do corpo humano com maior acometimento da dor foi a cervical seguida da lombar e ombros.

Descritores: Cervicalgia, Disfunção temporomandibular, Dor generalizada, Dor miofascial.

\section{INTRODUCTION}

Temporomandibular disorders (TMD) are represented by musculoskeletal abnormalities involving a large spectrum of clinical temporomandibular joint (TMJ) and masticatory muscles problems. These disorders are primarily characterized by pain, joint sounds and irregular or limited jaw function ${ }^{1}$ TMD etiology is multifactorial, including parafunctional and inadequate postural habits, bruxism, occlusal changes, overload, trauma, growth changes and stress ${ }^{2}$. 
Its pathophysiology is not yet clearly defined by the literature and it may have characteristics similar to other orofacial system diseases, or even as comorbidity of such changes ${ }^{3}$. There is comorbidity when two diseases have correlation and temporal continuity, and may appear simultaneously or one precede the other with more than casual association, and may share common pathophysiological aspects and clinical characteristics ${ }^{4}$, which often leads to diagnostic difficulty in the dental clinic. Trigeminal neuralgia, pulpitis, migraine, tension headache and fibromyalgia ${ }^{5,6-18}$ are some of the most common TMD-related comorbidities.

TMD is considered a chronic disease, being muscular TMD a functional pain syndrome with characteristics similar to cervical pain, fibromyalgia, interstitial cystitis, irritable bowel syndrome and chronic fatigue syndrome $e^{3,5,8}$. These conditions seem to have common etiologic factors which explain major comorbidity of symptoms.

Its pathophysiological mechanisms are still being studied ${ }^{9}$ and seemingly show changes in sensory processing with increased neuronal membrane excitability, increased substance $P$ levels, NMDA receptors activation, increased brain areas responsible for pain processing and decreased inhibitory influence of dorsal horn neurons on descending pain system, thus facilitating the development of central sensitization ${ }^{10}$ and perpetuating pain.

Clinical studies have shown that TMD patients may have several comorbidities, such as migraine, fibromyalgia, sleep disorders, anxiety and depression, and myofascial pain in addition to orofacial pain ${ }^{11-13}$ which may worsen pain and influence the possibility of developing central sensitization ${ }^{6,14,15}$.

TMD may also influence the management of other pain presentations. A double-blind randomized study in females with migraine and TMD has shown that migraine would only improve when both conditions were treated ${ }^{11}$.

With regard to fibromyalgia, it is important to identify whether just masticatory muscles are involved with TMD or there is a generalized muscle pain where both diseases may be present, thus potentiating diffuse pain. Depression and sleep disorders are frequent among fibromyalgia patients and could be responsible for TMD chronicity when concomitant ${ }^{16}$.

In the relationship between myofascial TMD and tension headaches, masticatory muscles pain is the common link and it is not totally clear whether it results from a specific peripheral response to central sensitization of there is local disease ${ }^{17}$. Orofacial dysfunctional signs and symptoms, such as teeth clenching, parafunctional habits, irregular jaw movement and temporomandibular noises are significantly increased in tension headache patients as compared to patients without tension headache ${ }^{17}$.

In case of trigeminal neuralgias it is extremely important not to confuse its diagnosis with dental problems or TMD because orofacial activities (such as teeth brushing, chewing) may trigger neuralgia crises and lead to unnecessary dental procedures, such as extractions or endodontic treatments. A study from the Universidade de São Paulo group has shown a sample of $38 \%$ of patients who could be victims of such confusion because they presented both diseases, trigeminal neuralgia and odontogenic diseases, among them TMD ${ }^{5}$.

Pain in other parts of the body in addition to face in TMD patients may impact pain control and contribute to persistence of masticatory muscles myofascial pain ${ }^{18-20}$. In addition, such comorbidity may be a risk factor for the development of TMD ${ }^{21,22}$.

So, for facial pain diagnosis and treatment it is important to recognize the relationship between muscle TMD pain and pain in different body parts, as well as to be aware of their prevalence in the population ${ }^{23,24}$

A way to evaluate patients' complaint of body pain are body surface maps used in medicine for the first time in $1949^{25}$ where patients are oriented to mark on the drawing the location and distribution of their pain ${ }^{24}$.

Drawings by patients have been used in different low back pain studies and some migraine, fibromyalgia, chronic and postsurgical cervical pain studies ${ }^{23}$. In orofacial studies, drawings were used by Hagberg ${ }^{14}$; Allerbring \& Haegers$\operatorname{tam}^{26}$; Hagberg, Hagberg \& Kopp ${ }^{27}$, and Blasberg \& Chalm$\mathrm{ers}^{28}$.

To improve the understanding of the extension to which facial muscle pain is followed by pain in other body parts, body map drawings of myofascial TMD patients were systematically analyzed.

This study aimed at evaluating the frequency of such reports and the location with higher prevalence of body pain.

\section{METHODS}

This study was carried out in the Centro de Pesquisa Odontológica São Leopoldo Mandic. Data were collected from medical charts, with records of assistance of specialization and master courses on TMD and orofacial pain, of patients referred to the orofacial pain center.

Clinical evaluation has followed the guidelines of the American Academy of Orofacial Pain (2103) and of the Diagnostic Criteria for Temporomandibular Disorders (DC-TMD) with regard to diagnostic criteria: muscle pain complaint in jaw, temple, ear, or in front of the ear, which is affected by movement and jaw function or parafunction. This familiar pain is replicated with masticatory muscle challenge test, that is, palpation of masseter and temporal muscles in three areas and asking patients to report whether pain is familiar or not and whether its spreads to a site different from the palpated region, thus minimizing the possibility of comorbidities influencing the diagnosis ${ }^{29}$.

TMD patients were oriented to mark in a human body contour drawing other body areas with pain for more than three months, considered chronic, thus avoiding pain caused by recent trauma or other wounds.

A sample of 480 medical charts of patients treated from 2010 to 2012 was retrospectively evaluated according to the following inclusion criteria: (a) diagnosis of myofascial pain in the orofacial region; (b) age between 25 and 60 years; (c) pres- 
ence of pain drawings showing other body pains reported by patients.

From 401 evaluated medical charts, 73 were excluded for having incomplete data, totaling a sample of 328 .

Body drawings used by patients to indicate pain area were divided in 45 anatomic areas according to Margolis, Tait \& $\mathrm{Krause}^{30}$, viewed from the front and back (Figure 1). The professional who had diagnosed TMD was the same orienting patients about filling the drawing.

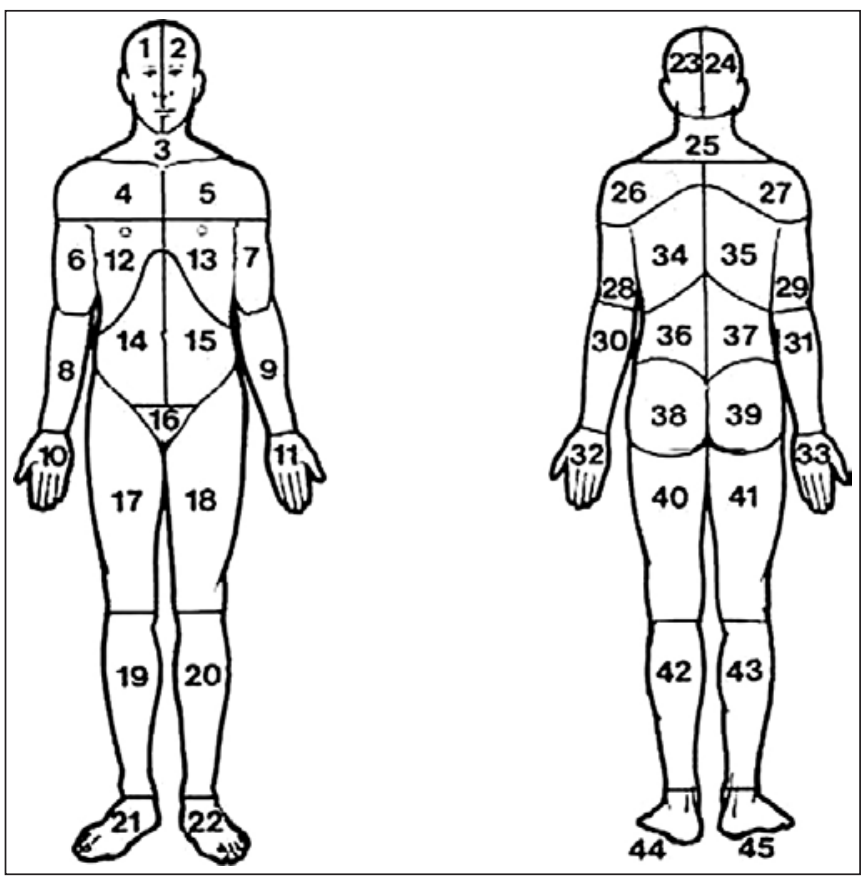

Figure 1. Body division into 45 anatomic areas

Cards were visually inspected by the chief researcher and more frequent pain areas were recorded. It was also evaluated in how many drawings pain was restricted to the face and how many had pain reports in other body parts, as well as the affected side (right, left or bilateral). In the frontal view, the drawing was divided in 22 areas and in the back view in 23 areas.

\section{Statistical analysis}

Statistical analysis of variance (ANOVA) and equality of two proportions and Chi-square tests were applied, being $\mathrm{p}<0.05$. This study was approved by the institution's Ethics Committee under protocol 0351/2009.

\section{RESULTS}

From 328 analyzed medical charts, $180(55 \%)$ had body pain on drawings (160 females and 20 males) and 148 (45\%) presented just facial pain (116 females and 32 males), with no difference between situations for this sample (Figure 2).

Areas with most frequent pain reports were cervical region followed by lumbar region, shoulders back view, shoulders front view and lower limbs front view (Figures 3 and 4).

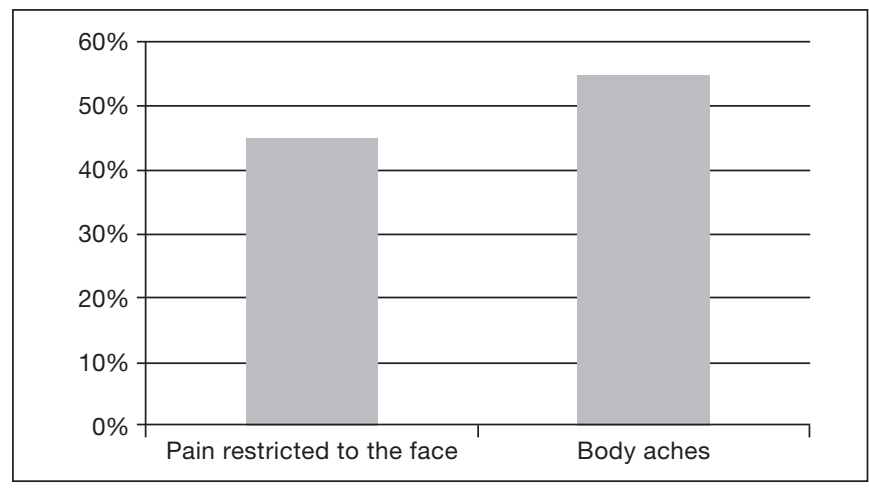

Figure 2. Percentage of body pain or just facial pain in TMD patients

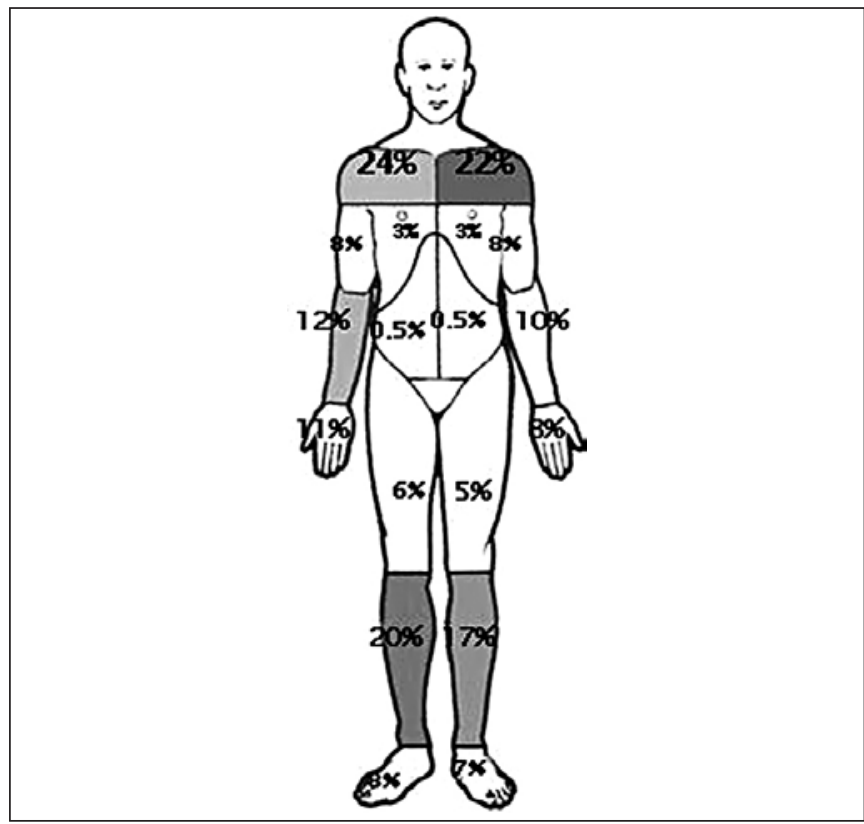

Figure 3. Frontal view of areas with most pain reports

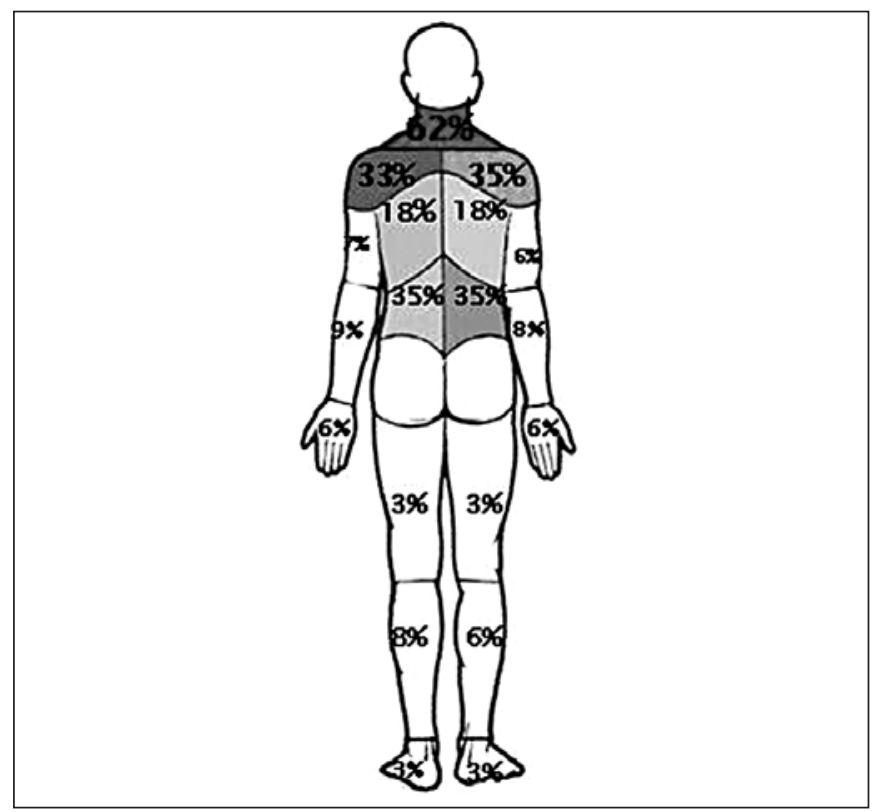

Figure 4. Back view of areas with most pain reports 
Prevalence with regard to gender shows that females were more affected by body pain as compared to males, with statistically significant difference $(\mathrm{p}<0.001)$ among females when the number of patients with just facial pain was compared to the number of patients with pain in other body parts (Figure 5).

To evaluate pain laterality (right or left), only 180 patients had both facial and body pain. Most evaluated patients have reported pain on both sides. Figure 6 shows this relationship on the face.

In the body, most reports were also bilateral (Figure 7).

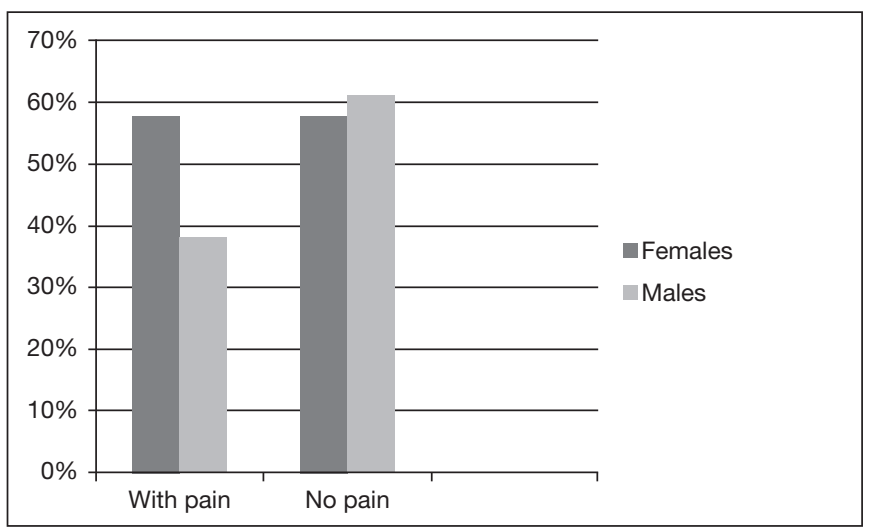

Figure 5. Body pain report in females and males

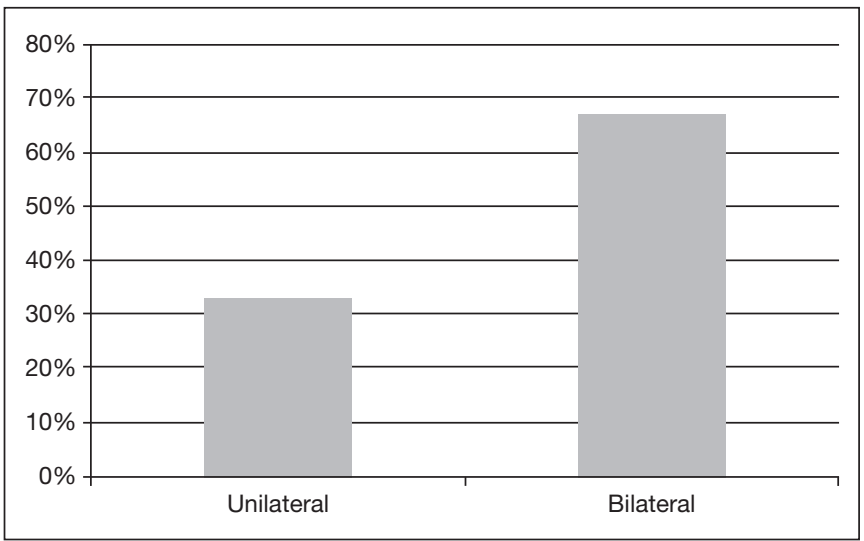

Figure 6. Pain in just one or both sides of the face

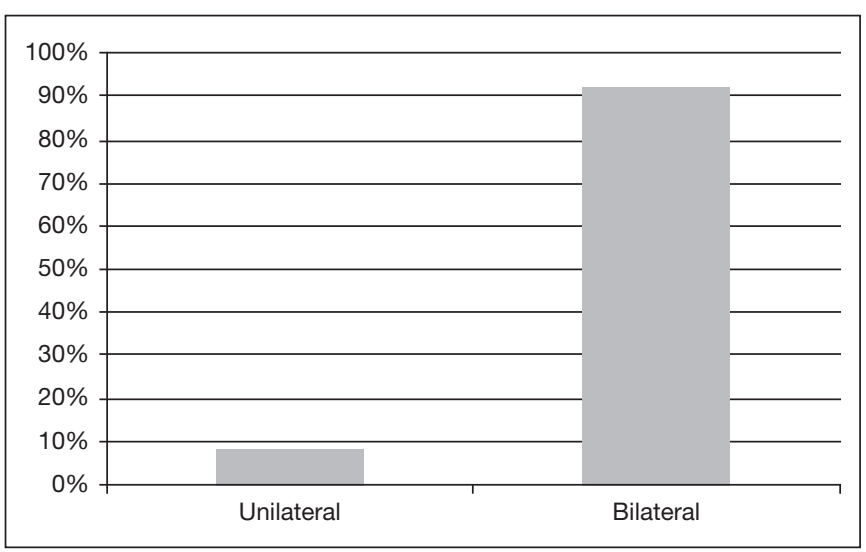

Figure 7. Pain in just one or both sides of the body

\section{DISCUSSION}

This study has found frequency of 55\% of body pain present for more than 3 months in patients with muscle TMD, similar to a study by Sipilä et al. ${ }^{22}$ who have also found $55 \%$ of generalized pain in TMD patients and lower than other studies, such as the study ${ }^{26}$ that has found $71 \%$ of body pain in TMD patients and the study of Türp et al..$^{24}$ which has found $67 \%$.

It is necessary to highlight that there is high frequency of pain outside the face, which may influence TMD management since pains may be added, generating central sensitization and worsening pain. Our objective was not to evaluate the etiology of such pains, however updated studies have shown that comorbidities such as fibromyalgia, myofascial pain and migraine $e^{9,10}$, among others, are closely related to TMD, thus increasing the need for diagnosis of each disease for total pain control. The use of body surface maps may be a tool to help evaluation of comorbidities which may influence TMD control.

With regard to areas affected by pain, our study has shown that patients with TMD and myofascial pain often have cervical pain. This was the region with the highest index of pain with $62 \%$ (females $64 \%$ and males $45 \%$ ), followed by lumbar and shoulders. Such results support the conclusion by De Laat et al. ${ }^{7}$ about the coexistence of TMD signs and functional limitation and cervical pain, when clinical TMD signs were compared to brain-cervical disorders. In this study ${ }^{24}, 30 \%$ of cases of pain were in the lumbar region, value close to that found in our study, which was $35 \%$ (34\% females and $47 \%$ males), and lower than a different study with $61 \%$ of back pain ${ }^{27}$.

A possible reason for the coexistence of TMD and cervical pain is based on the neurophysiologic conversion and sensitization principle. A constant nociceptive input in second order neurons may increase neuronal sensitivity and, with this, non-nociceptive impulses of other areas within the same segment converging to such neurons may increase the nociceptive sensation, that is, frequent impulses coming from the upper region of the trapezium may increase trigeminal spinal nucleus sensitivity and so non-nociceptive stimuli in the masticatory system could lead to painful sensation in the trigeminal region ${ }^{6}$. In these cases, patients have painful sensation in orofacial and cervical regions.

With regard to gender, our study findings have shown that most patients looking for TMD management are females, in a total of 276 as compared to 52 males. These data are already known by the literature where females have more TMD symptoms as compared to males ${ }^{19,21}$. Generalized pain was also more often reported by females, confirming data which report higher prevalence of generalized pain in females ${ }^{27}$.

The association between widespread pain and TMD in females may be important for collective public health, since currently females have a very important role also in the economic lives of families and the presence of both situations could keep them away from work for a larger period of time, thus causing social problems ${ }^{13}$. It was observed that females with myofascial pain and history of concomitant widespread 
pain were more prone to having depression as compared to females with just orofacial pain.

Considering the laterality of pain, it was observed that bilateral reports were the most frequent, both in face (67.2\%) and body (92\%), which confirms a different study ${ }^{28}$ where $66 \%$ of cases of pain were bilateral. Türp et al. ${ }^{24}$ have also reported that bilateral pain was present in $82.5 \%$ of the sample. Since there are evidences that muscle TMD may be associated to pain in different body regions, early interventions should be the objective of the multidisciplinary team.

Our results stress the need for improving the understanding of comorbidities affecting TMD patients to improve treatment and provide their control.

\section{CONCLUSION}

Most patients with temporomandibular disorder had pain in other body parts different from the face. Most common region marked on human body drawings was cervical, followed by lumbar and shoulders.

\section{REFERENCES}

1. Carlsson GE, Magnusson T, Guimarães AS. Tratamento das disfunçôes temporomandibulares na clínica odontológica. São Paulo: Quintessence; 2006.

2. Buckingham RB, Braun T, Harinstein DA, Oral K, Bauman D, Bartynski W, et al. Temporomandibular joint dysfunction syndrome: a close association with systemic joint laxity (the hypermobile joint syndrome). Oral Surg Oral Med Oral Pathol. 1991;72(5):514-9.

3. Stiesch-Scholz M, Fink M, Tschernitschek H. Comorbidity of internal derangement of the temporomandibular joint and silent dysfunction of the cervical spine. J Oral Rehabil. 2003;30(4):386-91

4. Lipton RB, Silberstein SD. Why study the comorbidity of migraine? Neurology 1994;44(10 Suppl 7):S4-5.

5. de Siqueira SR, da Nóbrega JC, Teixeira MJ, de Siqueira JT. Masticatory problems after balloon compression for trigeminal neuralgia: a longitudinal study. J Oral Rehabil. 2007;34(2):88-96

6. Furquim BD, Flamengui LM, Conti PC. TMD and chronic pain: a current view. Dental Press J Orthod. 2015;20(1):127-33.

7. De Laat A, Meuleman H, Stevens A, Verbeke G. Correlation between cervical spine and temporomandibular disorders. Clin Oral Investig. 1998;2(2):54-7.

8. Visscher CM, Lobbezoo F, de Boer W, van der Zaag J, Naeije M. Prevalence of cervical spinal pain in craniomandibular pain patients. Eur J Oral Sci. 2001;109(2):76-80

9. Kim SE, Chang L. Overlap between functional GI disorders and other functional syndromes: what are the underlying mechanisms? Neurogastroenterol Motil. 2012;24(10):895-913.

10. Latremoliere A, Woolf CJ. Central sensitization: a generator of pain hypersensitivity by central neural plasticity. J Pain. 2009;10(9):895-926.
11. Goncalves DA, Camparis CM, Speciali JG, Castanharo SM, Ujikawa LT, Lipton RB, et al. Treatment of comorbid migraine and temporomandibular disorders: a factorial, double-blind, randomized, placebo-controlled study. J Orofac Pain. 2013;27(4):32535 .

12. da Silva LA, Kazyiama HH, de Siqueira JT, Teixeira MJ, de Siqueira SR. High prevalence of orofacial complains in patients with fibromyalgia: a case-control study. Oral Surg Oral Med Oral Pathol Oral Radiol. 2012;114(5):e29-34.

13. Raphael KG, Marbach JJ, Klausner J. Myofascial face pain. Clinical characteristics of those with regional vs. widespread pain. J Am Dent Assoc. 2000;131(2):161-71.

14. Hagberg C. General musculoskeletal complaints in a group of patients with craniomandibular disorders (CMD). A case control study. Swed Dent J. 1991;15(4):179-85.

15. McMillan AS, Wong MC, Zheng J, Luo Y, Lam CL. Widespread pain symptom and psychological distress in southern Chinese with orofacial pain. J Oral Rehabil 2010;37(1):2-10.

16. Velly AM, Look JO, Schiffman E, Lenton PA, Kang W, Messner RP, et al. The effect of fibromyalgia and widespread pain on the clinically significant temporomandibular muscle and joint pain disorders--a prospective 18-month cohort study. J Pain. 2010;11(11):1155-64

17. Silva Jr AA, Brandão KV, Faleiros BE, Tavares RM, Lara RP, Januzzi E, et al. Temporomandibular disorders are an important comorbidity of migraine and may be clinically difficult to distinguish them from tension-type headache. Arq Neuropsiquiatr. 2014;72(2):99-103.

18. Lim PF, Smith S, Bhalang K, Slade GD, Maixner W. Development of temporomandibular disorders is associated with greater bodily pain experience. Clin J Pain. 2010;26(2):116-20.

19. Rammelsberg P, LeResche L, Dworkin S, Mancl L. Longitudinal outcome of temporomandibular disorders: a 5-year epidemiologic study of muscle disorders defined by research diagnostic criteria for temporomandibular disorders. J Orofac Pain. 2003;17(1):9-20.

20. Macfarlane TV, Blinkhorn AS, Davies RM, Kincey J, Worthington HV. Predictors of outcome for orofacial pain in the general population: a four-year follow-up study. J Dent Res. 2004;83(9):712-7.

21. John MT, Miglioretti DL, LeResche L, Von Korff M, Critchlow CW. Widespread pain as a risk factor for dysfunctional temporomandibular disorder pain. Pain 2003;102(3):257-63

22. Sipilä K, Ylöstalo PV, Joukamaa M, Knuuttila ML. Comorbidity between facia pain, widespread pain, and depressive symptoms in young adults. J Orofac Pain. 2006;20(1):24-30

23. Steinmetz A, Zeh A, Delank KS, Peroz I. Symptoms of craniomandibular dysfunction in professional orchestra musicians. Occup Med. 2014;64(1)17-22.

24. Türp JC, Kowalski CJ, O'Leary N, Stohler CS. Pain maps from facial pain patients indicate a broad pain geography. J Dent Res. 1998;77(6):1465-72.

25. Cummings GS, Routan JL. Accuracy of the unassisted pain drawings by patients with chronic pain. J Orthop Sports Phys Ther. 1987;8(8):391-6.

26. Allerbring M, Haegerstam G. Characteristics of patients with chronic idiopathic orofacial pain. A retrospective study. Acta Odontol Scand. 1993;51(1):53-8

27. Hagberg C, Hagberg M, Kopp S. Musculoskeletal symptoms and psychosocial factors among patients with craniomandibular disorders. Acta Odontol Scand. 1994;52(3):170-7.

28. Blasberg B, Chalmers A. Temporomandibular pain and dysfunction syndrome associ ated with generalized musculoskeletal pain: a retrospective study. J Rheumatol Suppl. 1989; 19:87-90

29. Koutris M, Visscher CM, Lobbezoo F, Naeije M. Comorbidity negatively the outcomes of diagnostic tests for musculoskeletal pain in the orofacial region. Pain. 2013;154(6):927-32

30. Margolis RB, Tait RC, Krause SJ. A rating system for use with patient pain drawings. Pain. 1986;24(1):57-65. 